Scientific paper

\title{
Computational POM and DFT Evaluation of Experimental in-vitro Cancer Inhibition of Staurosporine-Ruthenium(II) Complexes: the Power Force of Organometallics in Drug Design
}

\author{
Taibi Ben Hadda, ${ }^{1, *}$ Zuhal K. Genc, ${ }^{2, *}$ Vijay H. Masand, ${ }^{3}$ Nadia Nebbache, ${ }^{4}$ \\ Ismail Warad, ${ }^{5}$ Shehdeh Jodeh, ${ }^{5}$ Murat Genc, ${ }^{6}$ Yahia N. Mabkhot, ${ }^{7}$ \\ Assem Barakat ${ }^{7}$ and Hector Salgado-Zamora ${ }^{8}$ \\ ${ }^{1}$ Laboratoire Chimie Matériaux, FSO, Université Mohamed Premier, Oujda 60000, Morocco \\ ${ }^{2}$ Faculty of Engineering, Department of Metallurgy and Materials Engineering, Adiyaman University, 02040, Adiyaman, Turkey \\ ${ }^{3}$ Department of Chemistry, Vidya Bharati College, Camp, Amravati, Maharashtra, India \\ ${ }^{4}$ Laboratoire de chimie appliquée, Université de Biskra, B.P. 145, RP. 07000 Biskra, Algérie \\ ${ }^{5}$ Department of Chemistry, Faculty of Science,Taibah University, Al-Madinah Al-Munawarah, 30002, Saudi Arabia \\ ${ }^{6}$ Department of Chemistry, Faculty of Science and Arts, Adiyaman University, 02040 Adiyaman, Turkey \\ ${ }^{7}$ Department of Chemistry, College of Science, King Saud University, P. O. Box 2455, Riyadh-11451, Saudi Arabia \\ ${ }^{8}$ Departamento de Química Orgánica, Escuela Nacional de Ciencias Biológicas, Instituto Politécnico Nacional, Mexico,
} DF 11340, Mexico

*Corresponding author: E-mail: taibi.ben.hadda@gmail.com,zuhalkaragoz23@gmail.com Tel: +2120666134178; Fax: +2120536500603

Received: 14-01-2015

\begin{abstract}
A computational Petra/Osiris/Molinspiration/DFT(POM/DFT) based model has been developed for the identification of physico-chemical parameters governing the bioactivity of ruthenium-staurosporine complexes $\mathbf{2 - 4}$ containing an antitumoral-kinase (TK) pharmacophore sites. The four compounds 1-4 analyzed here were previously screened for their antitumor activity, compounds $\mathbf{2}$ and $\mathbf{4}$ are neutral, whereas analogue compound $\mathbf{3}$ is a monocation with ruthenium(II) centre. The highest anti- antitumor activity was obtained for compounds $\mathbf{3}$ and $\mathbf{4}$, which exhibited low $\mathrm{IC}_{50}$ values $(0.45$ and $8 \mathrm{nM}$, respectively), superior to staurosporine derivative (pyridocarbazole ligand $\left.1,150 \cdot 10^{3} \mathrm{nM}\right)$. The $\mathrm{IC}_{50}$ of $\mathbf{3}(0.45 \mathrm{nM})$, represents 20,000 fold increased activity as compared to staurosporine derivative 1 . The increase of bioactivity could be attributed to the existence of pi-charge transfer from metal-staurosporine to its $\left(\mathrm{CO}^{\delta-}-\mathrm{NH}^{\delta+}\right)$ antitumor pharmacophore site.
\end{abstract}

Keywords: Cancer-Kinase (CK), antitumor agents, ruthenium-staurosporine complexes, DFT, Petra/Osiris/Molinspiration (POM) analyses.

\section{Introduction}

Staurosporine derivatives (Figure 1) have been thoroughly studied in organic and inorganic chemistry. Some of these compounds have been semi-synthesized for industrial, biological, and medicinal aims. Moreover, the staurosporine derivatives are regarded as excellent agents not only for their affinity to complex the kinase enzymes ${ }^{1}$ but also to form stable bioactive and selective complexes with the ions of ruthenium(II). ${ }^{2}$ These com- 
<smiles>O=C1NC(=O)c2c1c1ccccc1c1[nH]c3ccccc3c21</smiles>

$1\left(\mathrm{IC}_{50}: 150 \mu \mathrm{M}\right)^{2}$

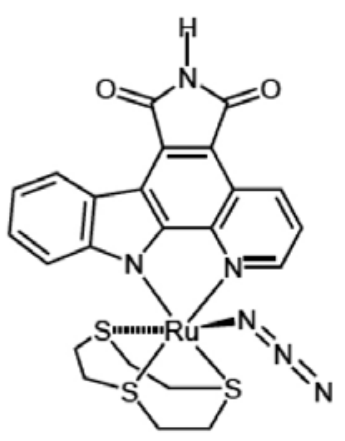

$2\left(\mathrm{IC}_{50}: 70 \mathrm{nM}\right)^{2}$

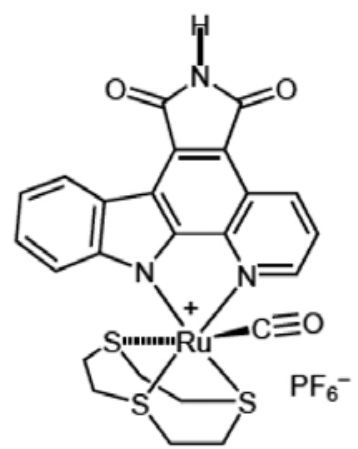

$3\left(\mathrm{IC}_{50}: 0.45 \mathrm{nM}\right)^{2}$

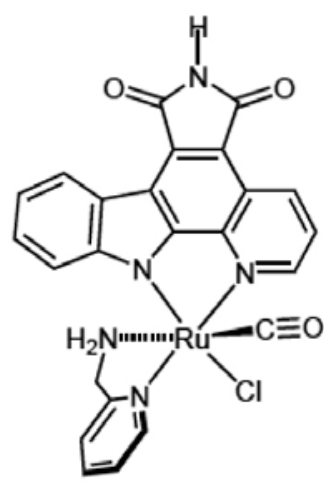

$4\left(\mathrm{IC}_{50}: 8 \mathrm{nM}\right)^{2}$

Figure 1. Molecular structure of the ruthenium-staurosporine compounds ${ }^{2}$ studied.

plexes are so efficient that it is often projected to use them in clinics. ${ }^{2,3}$ The protein kinase inhibition for the treatment of cancer via staurosporine and their ruthenium(II) complexes, rank as an attractive and extensively researched topic. ${ }^{3-6}$

Other studies on the interaction between $\mathrm{Pd}(\mathrm{II})$ and $\mathrm{Pt}(\mathrm{II})$ complexes of small molecules and DNA has been the focus of similar recent research in the scope of life science, chemistry, clinical medicine and genetics. ${ }^{7,8}$ These studies are very useful for investigating the structure and biological function of DNA, kinases and elucidating the damage mechanism of DNA but Ru(II) complexes are less toxic than other transition metal complexes. For this reason we focalize all our attention on $\mathrm{Ru}$-staurosporine complexes.

The inhibition efficiency of such drugs depends essentially on the structure of the inhibitor itself, which includes the number of active functional group centers $(\mathrm{NH}-\mathrm{C}=\mathrm{O})$ in the molecule, the nature of the metal, and the kinase structure. The structure and the lone electron pairs in the $\mathrm{O}, \mathrm{N}$ heteroatoms are important features that determine the chelation/interaction of these compounds with the metallic ion and biotargets.

The inhibition efficiency of bacteria, virus, parasite, and fungus, has been found to be closely related to drug bioavailability and molecular physico-chemicalgeometric-tautomeric properties for different kinds of organic drugs. ${ }^{9-22}$ Recently, it has been shown that the kinase inhibition by an organometallic systems under biological condition may be significantly facilitated if a ligand containing an anti-kinase pharmacophore $(\mathrm{NH}-\mathrm{C}=\mathrm{O})$, a bidentate $\mathrm{N}, \mathrm{N}$ coordinative site (staurosporine derivatives) and non-toxic metal (ruthenium) are available..$^{2-6}$

The cancer inhibition of kinase enzymes through organic drugs has been the subject of different theoretical investigations. However, to our knowledge no group has carried out a rational correlation between experimental screenings efficiencies of anti-kinase drugs and the results of Petra/Osiris/Molinspiration (POM) analyses.

The utility of analysis of impact of coordination of drugs to transition metals on their bioactivity is of great importance in answering some fundamental questions in medicinal chemistry and biological chemistry, such as selectivity control (whether or not a given complex will be toxic). An excellent source that illustrates this concept well is the interesting work published by Eric Meggers $e t$ $a l .^{2-6}$

The development of theoretical scales of electrophilicity and nucleophilicity of pharmacophore site is also desirable and crucial, as a validated theoretical scale may be further used to project the global reactivity onto particular regions on the complexed drug.

There are different ways to increase the bioactivity of drugs; by modeling their bioavailability and controlling their electronic structure. A suitable theoretical concept is that proposed by Ben Hadda et al. ${ }^{9-25}$ apropos of definition of pharmacophore site. The best descriptors for studying and identifying the type of pharmacophore site (antibacterial, antiviral or antitumor) are the description in detail of local electrophilicity and the nucleophilicity of each functionalized group and their spatial arrangement.

Recently, Ben Hadda et al. introduced some geometrical parameters, bioavailability, structural complementarily global and local (regional) nucleophilicity to establish modern definition of different pharmacophore sites. ${ }^{9-25}$

For these reasons, we constructed a platform of some of the key bioinformatic model in order to predict and characterize the antitumor drugs performance of the tested series of staurosporine-ruthenium(II) complexes. Our aim in this work is to give a deeper insight into the coordination effect of transition metal (ruthenium) to bioactive drug (staurosporine), on the inhibition efficiency of ruthenium-staurosporine complexes (Figure 1) using POM and DFT analyses. 


\section{Experimental}

\section{1. DFT Method}

The molecular modeling was performed using Gaussian 09 program package for calculations. In the present work, the calculations have been carried out at (DFT/B3LYP) method with 6-31+G(d,p) basis set. Electron correlations were included using Becke3-Lee-Yang-Parr (B3LYP) procedure. ${ }^{26}$ This contains Becke's gradient exchange corrections, Lee, Yang and Parr correlation functional and/or Vosko, Wilk and Nusair correlation functional. ${ }^{27}$

\section{2. POM Analyses}

One of the practical problems associated to the synthetic drugs is the existence of various side effects. For a molecule to be a potential drug, besides having a good biological activity, it must have good pharmacokinetic properties in biological systems. To access the pharmacokinetic profile of the synthesized molecules, we used well established in silico tools such as Osiris, Petra and Molinspiration, which have been validated with almost 7000 drug molecules available on the market.

\section{Results and Discussion}

\section{1. POM Analyses of Compounds 1-5}

The analysis of theoretical toxicity risks for the staurosporine (STR) and its organic derivative $\mathbf{1}$ using the Osiris program showed that compound $\mathbf{1}$ and probably the rest of series 2-4 (Figure 2) are less toxic than standard clinical drugs (camptothecins) and can be used as therapeutic agents. From the data evaluated in Table 1, all structures are supposed to be non-mutagenic when run through the mutagenicity assessment of coordinated system and, as far as irritating and reproductive effects are concerned, all the compounds are at low risk comparable with standard drugs used. The hydrophilicity character of each compound has been expressed in terms of the $\operatorname{cLog} P$ value. It has been established that the absorption or permeation is greatly affected by the hydrophilicity (value of $\operatorname{cLog} P$ ). Accordingly, when $\operatorname{cLog} P$ is higher than 5, the absorption or permeation decreases. On this basis, most of compounds 1-4 have cLog $P$ values within the acceptable criteria and are active at different $\mathrm{IC}_{50}$ because another crucial parameter should be taken in consideration. This does not concern the geometrical conformation of phar-

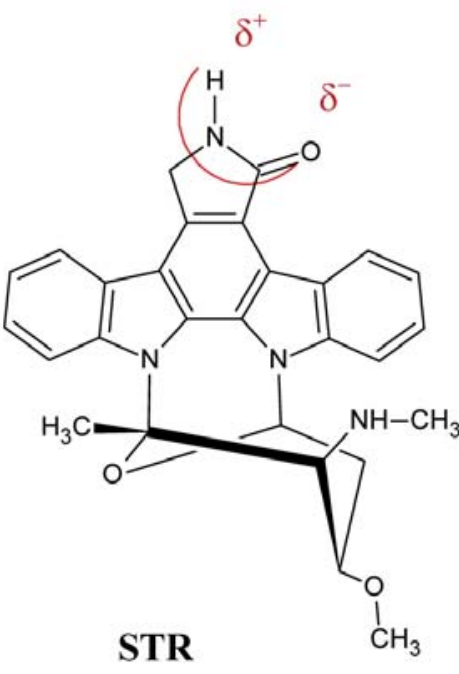

(Staurosporine)

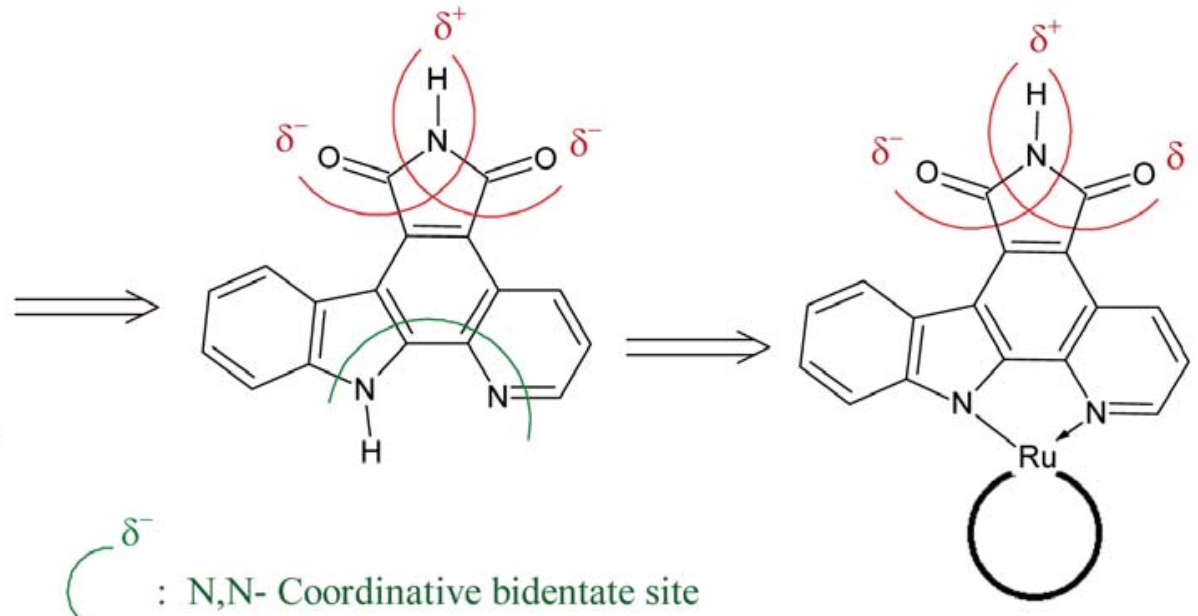

Electron reservoir

\section{Anti-Kinase pharmacophore site}

Figure 2. Series of Ru-staurosporine complexes with anti-tumoral pharmacophore site.

Table 1. Osiris calculations of toxicity risks of staurosporine (STR) and its derivative (1).

\begin{tabular}{lccccccrrr}
\hline Compd. & MW & \multicolumn{4}{c}{ Toxicity Risks ${ }^{[\mathrm{a}]}$} & \multicolumn{3}{c}{ Osiris calculations $^{[\mathrm{b}]}$} \\
\hline 1 & & MUT & TUM & IRRI & REP & cLogP & Sol & DL & DS \\
STR & 287 & +++ & --- & +++ & +++ & 2.41 & -4.72 & 2.28 & 0.42 \\
\hline
\end{tabular}

Higly toxic: (---), Slightly toxic: (+), Not toxic (+++). ${ }^{[a]}$ MUT: Mutagenic, TUM: Tumorigenic, IRRIT: Irritant, RE: Reproductive effective.

${ }^{[b]}$ Sol: Solubility, DL: Druglikness, DS: Drug-Score. STR : Staurosporine. 
Table 2. Molinspiration calculations of staurosporine derivative (1) and its complexes (2-4).

\begin{tabular}{lrcccccrrrr}
\hline \multirow{2}{*}{ Compd. } & \multicolumn{4}{c}{ Molinspiration calculations [a] } & \multicolumn{4}{c}{ Drug-likeness } \\
& TPSA & NONH & NV & VOL & GPCRL & ICM & KI & NRL & PI & EI \\
\hline 1 & 79 & 2 & 0 & 236 & 0.01 & 0.02 & 0.96 & .48 & 0.21 & 0.56 \\
2 & 109 & 1 & 1 & 428 & 0.12 & 0.15 & 0.33 & -0.56 & -0.02 & 0.42 \\
3 & 76 & 1 & 1 & 480 & 0.00 & 0.28 & 0.11 & 0.64 & 0.08 & 0.14 \\
4 & 96 & 3 & 1 & 394 & 0.04 & 0.18 & 0.25 & 0.70 & 0.25 & 0.28 \\
STR & 69 & 2 & 0 & 410 & 0.37 & 0.23 & 1.50 & -0.18 & 0.35 & 0.86 \\
\hline
\end{tabular}

[a] TPSA: Total molecular polar surface area; NONH: number of OH---N or O---NH interaction, NV: number of violation of five Lipinsky rules [50, 51]; VOL: volume. ${ }^{[b]}$ GPCRL: GPCR ligand; ICM: Ion channel modulator; KI: Kinase inhibitor; NRL: Nuclear receptor ligand; PI: Protease inhibitor; EI: Enzyme inhibitor. STR : Staurosporine.

macophore because it is fixed for all compounds $\mathbf{1}-\mathbf{4}$. The absorption, distribution characteristics and bioactivity were proved to be dependent on the geometrical parameter and the aqueous solubility of each compound. Consequently, the bad absorption of tested staurosporine-ruthe-

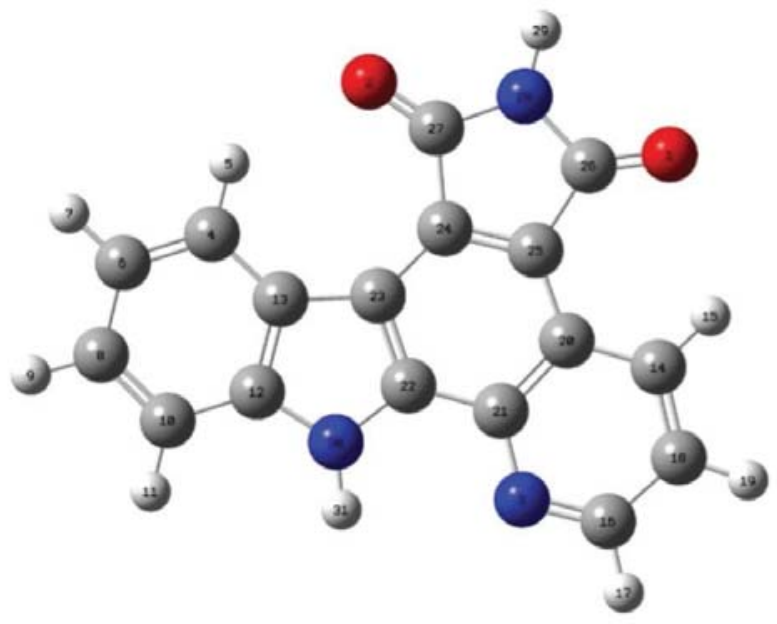

Compound 1

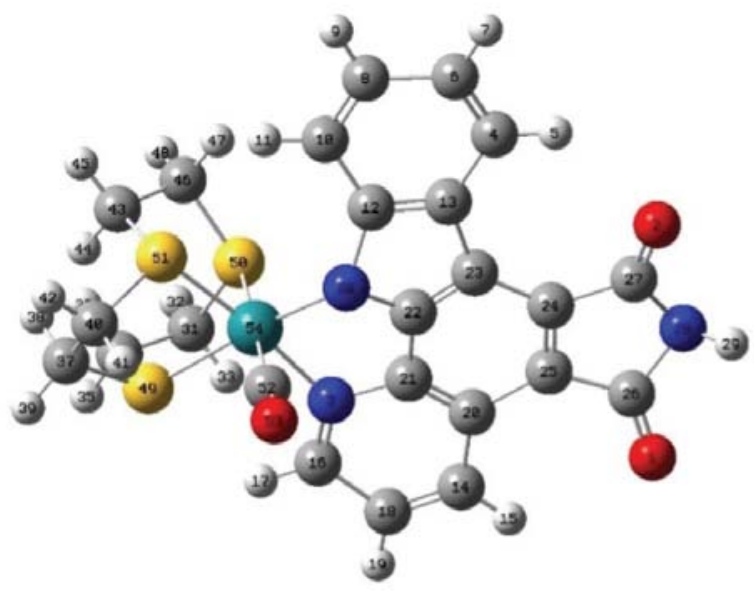

Compound 3
nium(II) complexes $\mathbf{2}-\mathbf{4}$ could presumably be due to their low solubility. ${ }^{28,29}$ Further, Table 2 shows drug-likeness of compounds 1-4, not in the comparable zone with standard drugs used. We have calculated overall drug-score (DS) for compounds 1-4 and compared with that of standard

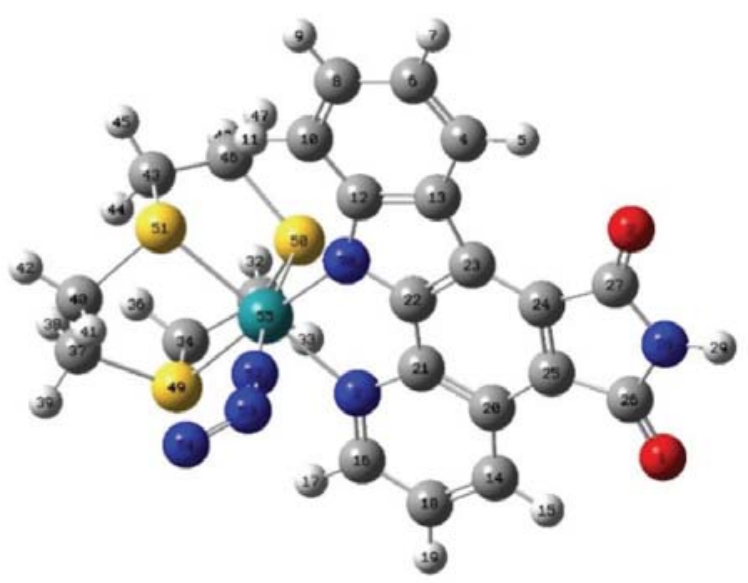

Compound 2

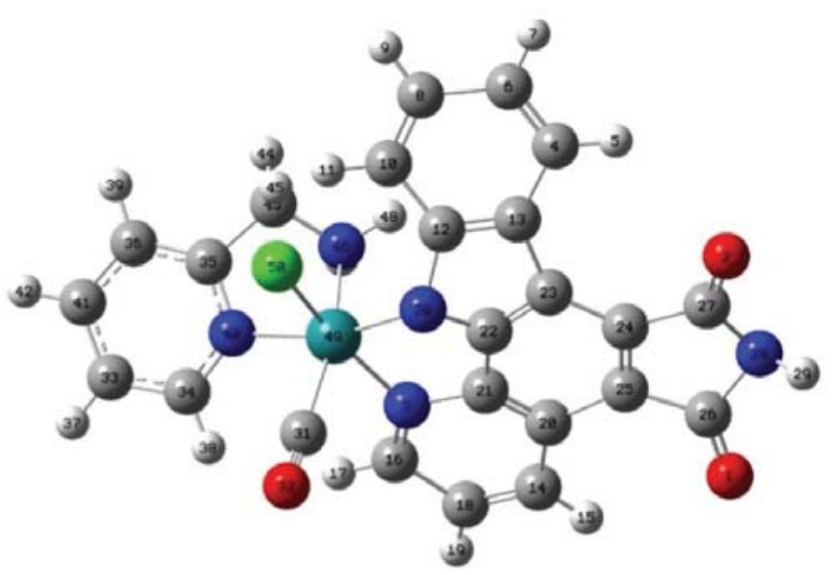

Compound 4

Figure 3. Optimized geometrical structure of compounds 1-4. 
drug (STR). The DS combines drug-likeness, $\operatorname{cog} P$, $\log$ $S$, molecular weight, and toxicity risks, in one handy value that may be used to judge the compound's overall potential to qualify for a drug. The reported compounds 2-4 showed low to moderate DS as compared with standard drug used STR (Table 1).

Incidentally, it is our opinion that DS and DL are not quite reliable since the values depend upon the program used. For this reason, supplementary DFT calculations will clarify this query.

\section{2. Frontier Molecular Orbitals}

Highest occupied molecular orbital (HOMO) and lowest unoccupied molecular orbital (LUMO) are the most important orbitals to characterize the chemical reac- tivity, $^{30,31}$ optical properties ${ }^{32}$ and biological activity. ${ }^{33}$ The energy gap between HOMO and LUMO is obtained by first optimization of structures 1-4 (Figure 3) as illustrated in Figure 4.

HOMO, HOMO-1, LUMO and LUMO+1 energies were calculated at B3LYP/6-311+G(d,p) and LANL2DZ theory level in order to understand influence of the structural properties of the Staurosporine and its complexes that are summarized in Table 3. As can be seen from Figures 4-7, for compound 1, HOMO is mainly delocalized on the aromatic ring and heteroatoms except pyrrole carbonyl oxygen; however LUMO is mainly delocalized on the indole ring and heteroatoms. For compound 2; the HOMO electrons are mainly delocalized on the $\mathrm{Ru}(\mathrm{II})$ and azido group, LUMO electrons are delocalized on the Staurosporine ring. For

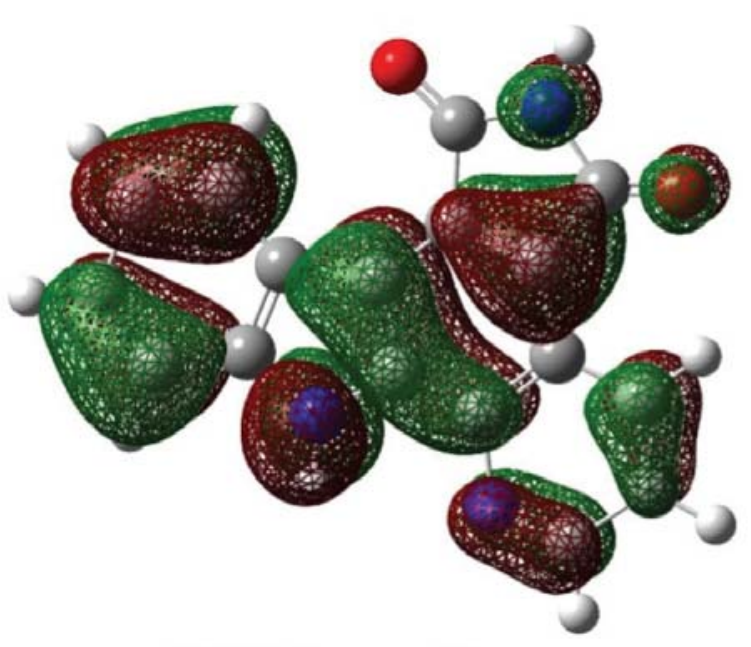

HOMO (Compound 1)

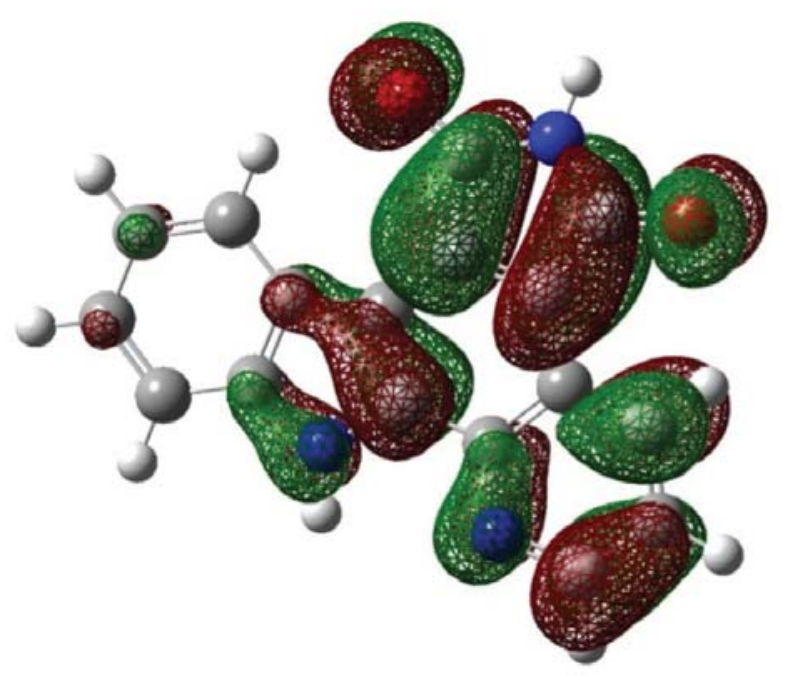

LUMO (Compound 1)

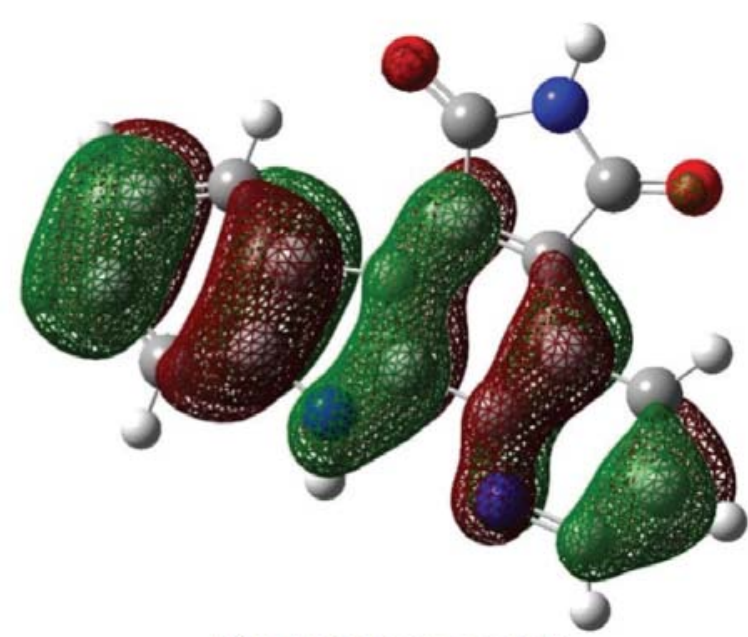

HOMO-1 (Compound 1)

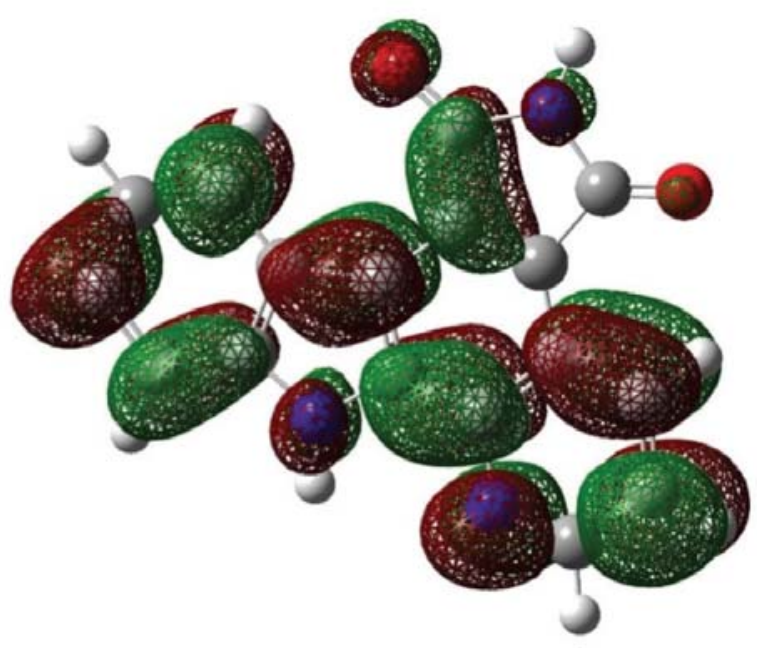

LUMO+1 (Compound 1)

Figure 4. HOMO and LUMO molecular orbitals of the staurosporine derivative N,N-ligand (1) using the 6-311+G(d,p) method. 


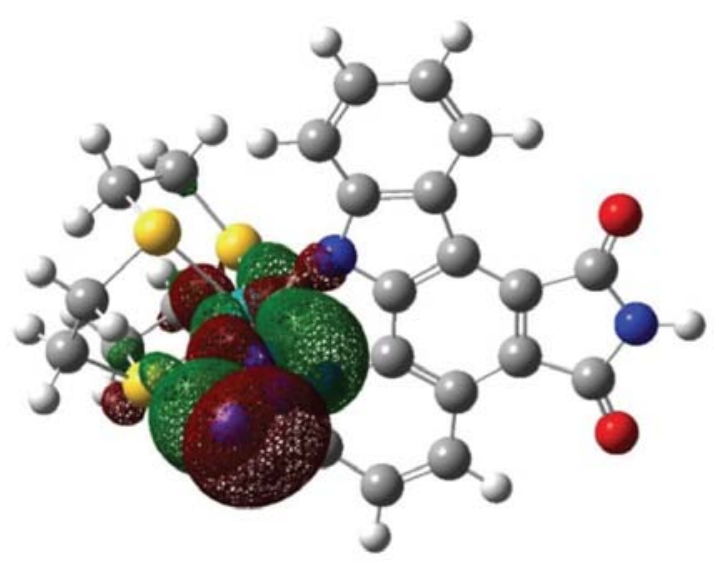

HOMO (Compound 2)

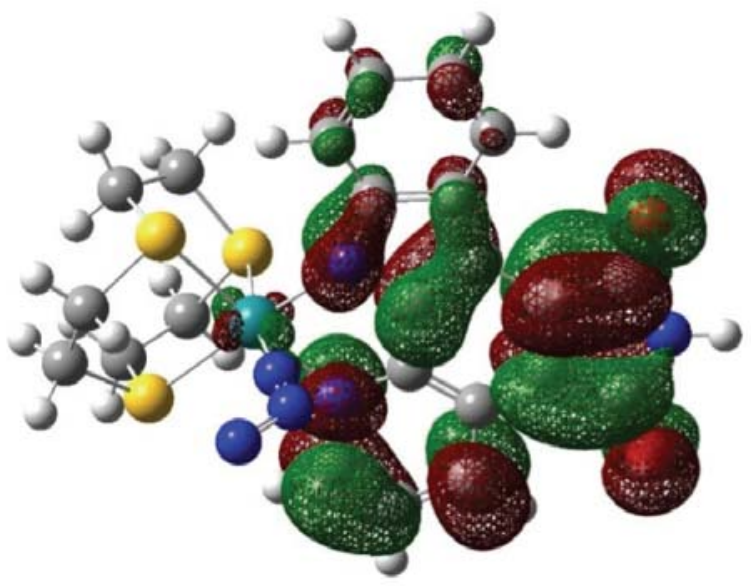

LUMO (Compound 2)

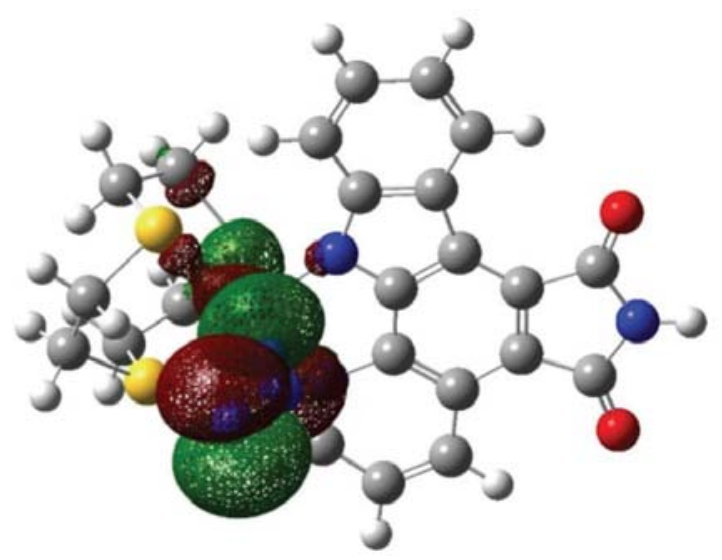

HOMO -1(Compound 2)

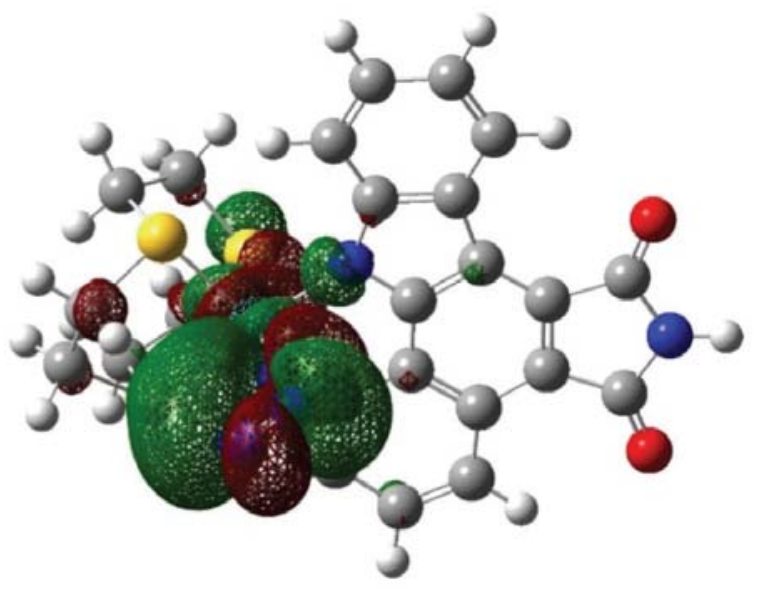

LUMO+1 (Compound 2)

Figure 5. HOMO and LUMO molecular orbitals of the Staurosporine complex (2) using the LANL2DZ method.

compound 3; the HOMO electrons are mainly delocalized on the $\mathrm{Ru}(\mathrm{II})$, oxygen atoms and pyrrole ring, while LUMO electrons are delocalized on the 1,4,7-trithiocyclononan ring. For complex 4; the HOMO electrons are mainly delocalized on the $\mathrm{Ru}(\mathrm{II}),-\mathrm{NH}_{2}$, indole ring, LUMO electrons are delocalized on the indole and pyridine ring. According to these results; generally HOMO and LUMO orbitals are mainly delocalized on the rings that mean p-antibonding type orbitals.

Various functional groups are the major active centers of the interraction. Indeed, the HOMO of these compounds does not contribute to an explanation of their inhibitory efficiency, but the HOMO-1 can carry out this role. In these cases, analysis of the effectiveness of kinase inhibition is based on the energy gaps (HOMO-1-LUMO+1). The chemical potential and nucleophilicity were estimated using the HOMO-1 and the LUMO (Figures 4-7; Table 3). However, the gap between the HOMO-1 and LU-
MO orbitals is an important factor that should be considered. The excellent enzyme kinase inhibitors are generally organic compounds that not only donate electrons to the positive charged amino acids of the enzyme but also accept free electrons of the imine groups of kinase enzymes.

By analyzing the HOMO-1-LUMO+1 energy gap values for these complexes (Table 3 ), it can be noted that for complexes 2-4, the HOMO-1-LUMO+1 energy gaps values are lower than those obtained for ligand free (1). Therefore, complexes 2-4 (containing electron rich organometallic moiety) are predicted to be better kinase enzyme inhibitors with gaps HOMO-LUMO (2: 0.03842, 3: $0.05054,4: 0.08147$ a.u.) than ligand free compound 1 (containing free bidentate electron-withdrawing group) (1: 0.12336 a.u.) as shown in Table 3.

These results are in total agreement with the experimental results (Table 4). The HOMO-LUMO energy gaps of these complexes are consistent with the experimental 


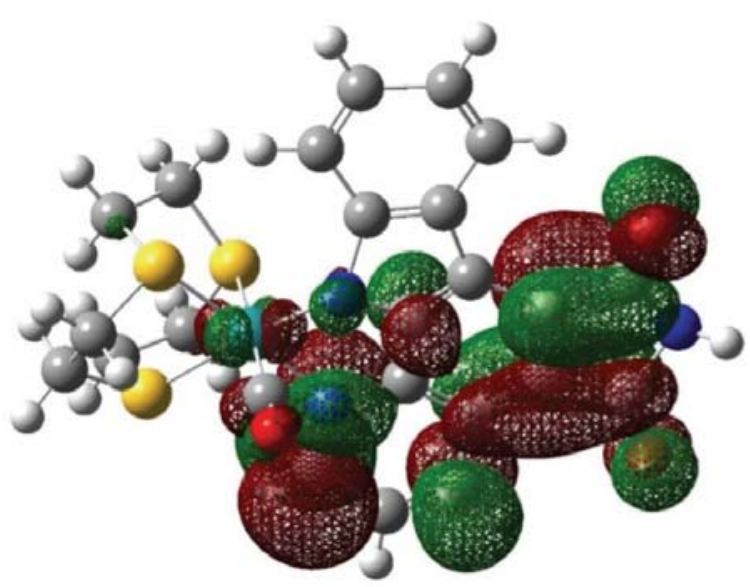

HOMO (Compound 3)

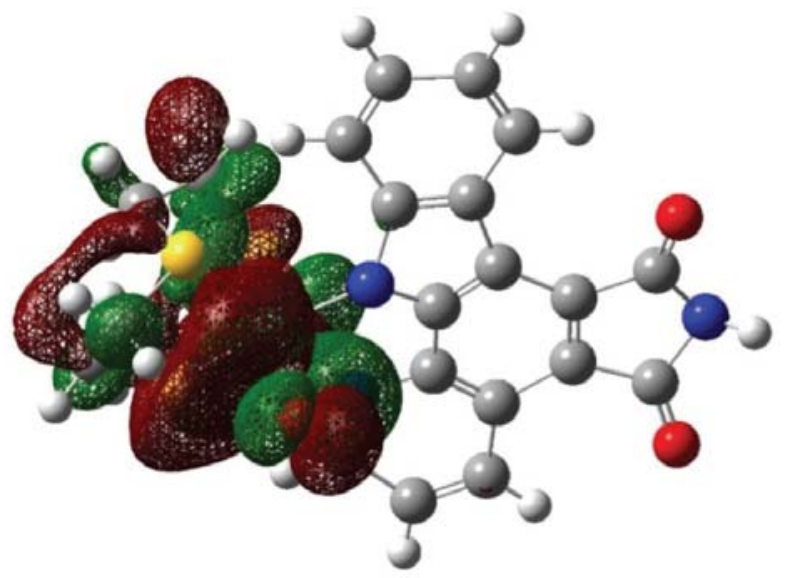

LUMO (Compound 3)

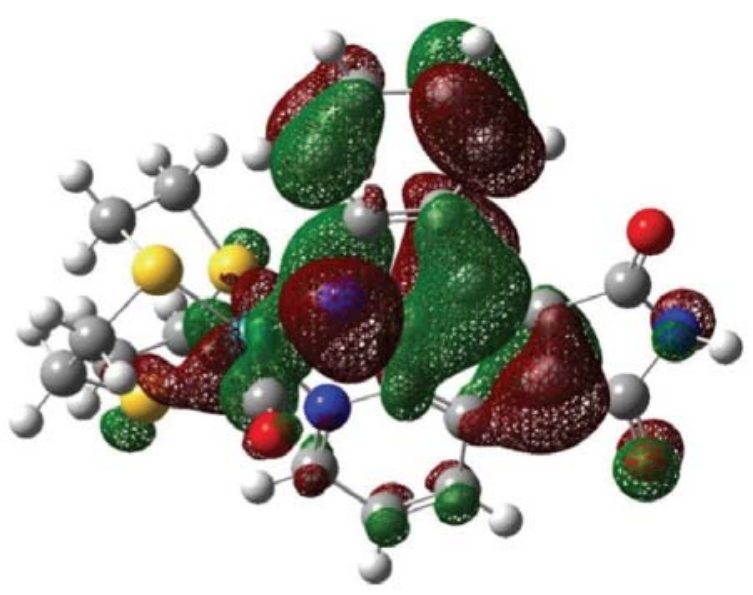

HOMO-1(Compound 3)

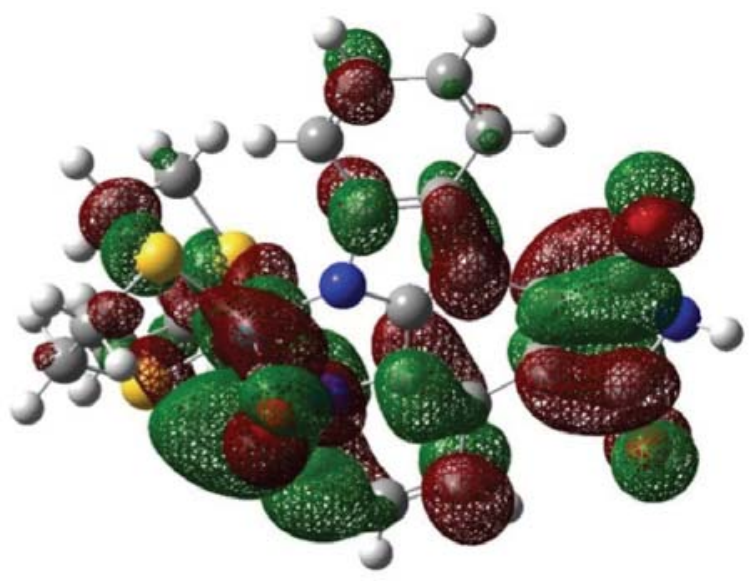

LUMO+1 (Compound 3)

Figure 6. HOMO and LUMO molecular orbitals of the staurosporine complex (3) using the LANL2DZ method.

$\mathrm{IC}_{50}$ values given in literature ${ }^{2-6}$ and the partial atomic charge obtained by calculations (Table 4). Furthermore, the two Oxygen atoms of the OCNHCO pharmacophore site are negatively charged, and the $\mathrm{IC}_{50}$ is low (more efficiency in bioactivity). The order obtained was $\mathbf{3}>\mathbf{4}>\mathbf{2}>$ 1 with O-charge: $-0.6349,-0.56,-0.6349,-0.5383$, respectively.

The structure of complex can affect the bioactivity by influencing not only the electron density of the functional pharmacophore site but also its proper bioavailability.
In order to rationalize the local bioactivity, we have calculated the local charge of each heteroatom. The results are summarized in Table 4 . The local atomic charges were obtained using DFT calculations

The distribution of the electron density shows that the compounds studied 1-4 have many active centers in nucleophilicity. The areas containing the nitrogen and oxygen atoms have more opportunity to form bonds with the metallic ruthenium(II) ions, by donating electrons of the heteroatoms to the metallic ions (Table 4). However,

Table 3. HOMO, HOMO-1, LUMO, LUMO+1 and $\Delta E$ energies (a.u.)

\begin{tabular}{llllccc}
\hline Compd. & HOMO & LUMO & HOMO-1 & LUMO+1 & HOMO-LUMO & HOMO-1-LUMO+1 \\
\hline $\mathbf{1}$ & -0.22915 & 0.10579 & -0.24174 & -0.07088 & 0.12336 & 0.17086 \\
$\mathbf{2}$ & -0.12373 & -0.09431 & -0.14660 & -0.06253 & 0.03842 & 0.08407 \\
$\mathbf{3}$ & -0.09299 & -0.04245 & -0.19200 & -0.03928 & 0.05054 & 0.15272 \\
$\mathbf{4}$ & -0.18283 & -0.10136 & -0.19945 & -0.07086 & 0.08147 & 0.12859 \\
\hline
\end{tabular}




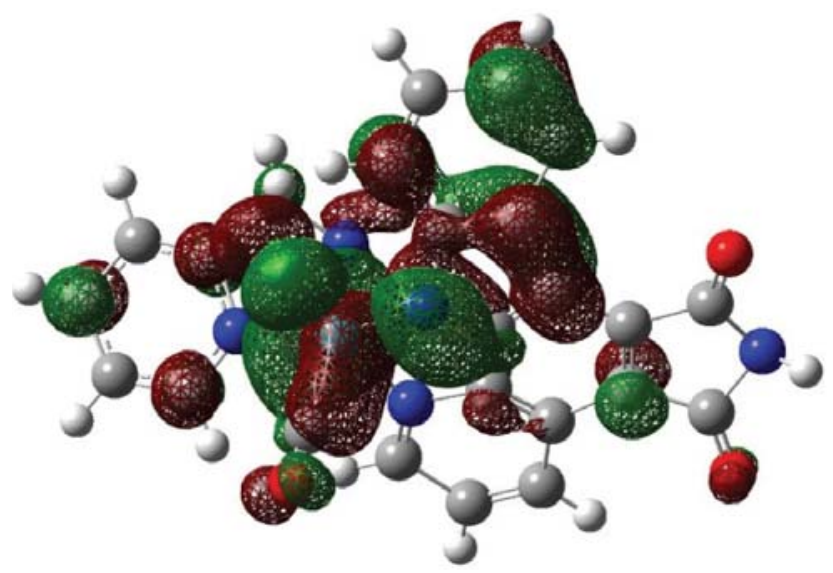

HOMO (Compound 4)

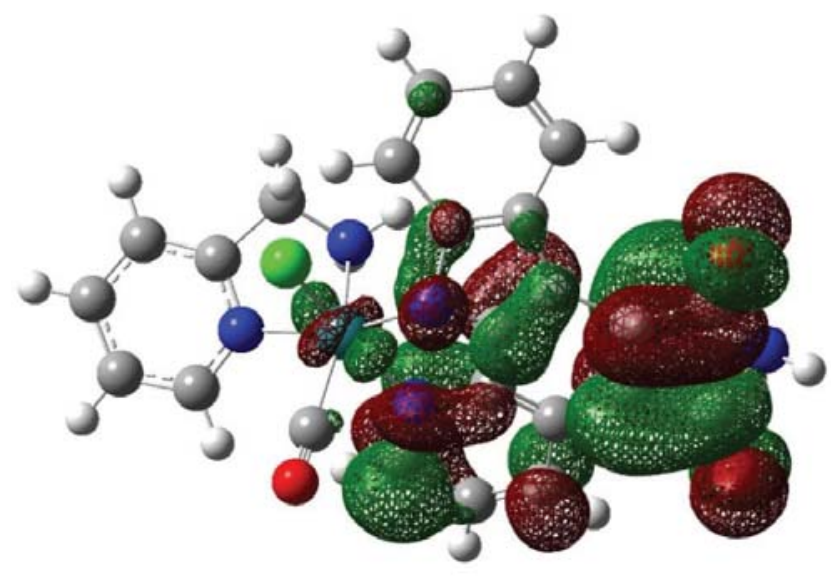

LUMO (Compound 4)

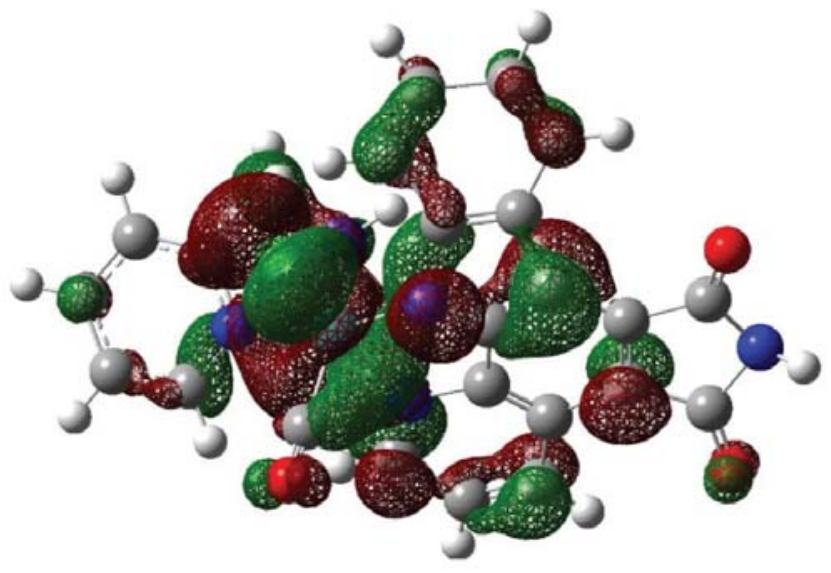

HOMO +1(Compound 4)

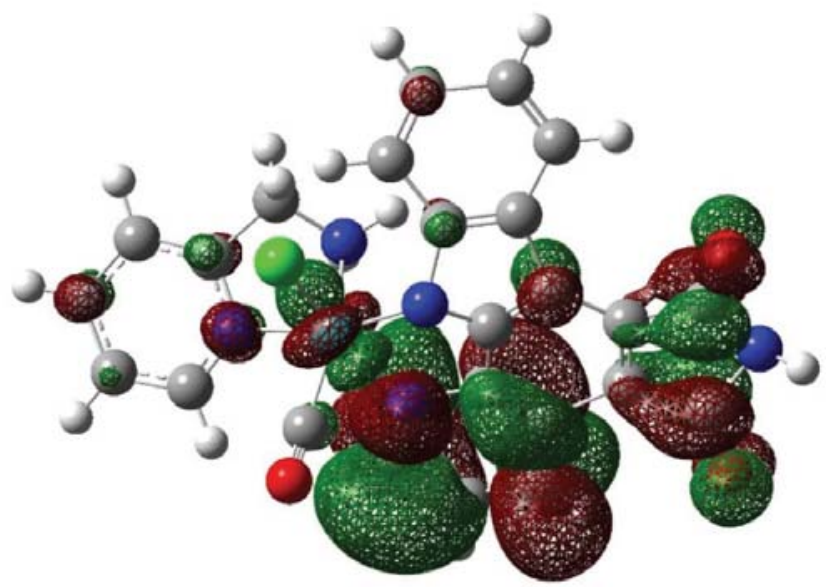

LUMO+1 (Compound 4)

Figure 7. HOMO and LUMO molecular orbitals of the staurosporine complex (4) using the LANL2DZ method.

Table 4. Electronic impact on antitumor activity of (OCNHCO) pharmacophore site by coordination of drug (1) to electron rich organometallic moiety (2-4).

\begin{tabular}{lccccccc}
\hline Compd & $\begin{array}{c}\mathbf{I C}_{\mathbf{5 0}} \\
(\mathbf{n M})\end{array}$ & $\mathbf{R u}$ & $\begin{array}{c}\text { Charge of Ru-(NN) } \\
\text { Organometallic Moiety }\end{array}$ & $\mathbf{N - 1}$ & $\mathbf{N - 2}$ & \multicolumn{3}{c}{$\begin{array}{c}\text { Charge of OCNHCO } \\
\text { Pharmacophore Site }\end{array}$} \\
& & --- & -0.3827 & -0.6016 & -0.5289 & 0.4422 & -0.5383 \\
\hline $\mathbf{1}$ & $150 \cdot 10^{3}$ & -0.4886 & -0.3827 & -0.4391 & -0.6292 & 0.4422 & -0.6349 \\
$\mathbf{2}$ & 70 & -1.0243 & -0.4561 & -0.5440 & -0.6292 & 0.4169 & -0.6349 \\
$\mathbf{3}$ & 0.45 & -0.3461 & -0.3979 & -0.4591 & -0.5808 & 0.2277 & -0.5605 \\
$\mathbf{4}$ & 8 & & & & & &
\end{tabular}

sites N1 and N2 are most favorable for electrophilic attack, in addition to oxygen in the case of $\mathbf{1}$. It is interesting to note that the negative transferred charge of $\mathrm{Ru}$ (II) have important effect on the efficiency of inhibition of enzyme, like the effect of the terminal substituents on the organometallic moiety. This is in perfect agreement with the experiments (3: $-1.0243 ; 2$ : $-0.4886 ; 4$ : -0.3461 u.a).

\section{Conclusions}

The present work provided additional structure-activity and structure-cytotoxicity information for the staurosporine-ruthenium(II) complexes family. Indeed, this study proved that a simple control of nature of simple coordination to non-toxic transition metals leads to com- 
pounds with high activities and reduced cytotoxicities of staurosporine as parent and clinical standard drug.

Tumor inhibition of kinase through staurosporine ligand and its complexes was elucidated by means of density functional theory (DFT)-derived reactivity indexes. The DFT calculated parameters and experimental cancer inhibition efficiency $\left(\mathrm{IC}_{50}\right)$ indicate that their inhibition effect is closely related to the frontier orbital energies, polarizability, electronic chemical potential and global nucleophilicity. The quantum chemistry calculations were performed at the B3LYP/6-31G(d) level. The theoretical results predicted by using DFT-based reactivity indexes, are in good agreement with experimental outcomes.

In comparing the percentages of inhibition efficiency $\left(\mathrm{IC}_{50}\right)$ of the studied compounds with the theoretical results, we note that their inhibitory effects are closely related to HOMO-1, HOMO-1-LUMO+1 gap, and the partial negative charge of Oxygen atoms of pharmacophore site. These parameters were calculated by the DFT method. The bioactivity decreases when HOMO-1 increases, and when the HOMO-1-LUMO+1 gap decreases. Therefore, complexes $\mathbf{2 - \mathbf { 4 }}$ are better kinase inhibitors (presence of donor organometallic moiety on the ligand- $\mathrm{Ru}$ ) than free ligand $\mathbf{1}$ (presence of withdrawing nitrogen bidente groups on the staurosporine derivative ring's). The DFT calculations indicate that it is not convenient to consider only a single parameter (partial charges). However, several parameters were considered to characterize the inhibitory activity of the molecules, in particularly bioavailability $(\operatorname{cog} P)$. The partial atomic charges of the series of complexes were discussed in a simple but precise manner.

\section{Acknowledgements}

The authors would like to extend their sincere appreciation to the Deanship of Scientific Research at king Saud University for its funding this Research group $\mathrm{N}^{\circ}$ (RG-007-1435-1436).

\section{References}

1. A. Huwe, R. Mazitschek, A. Giannis, Angew. Chem. Int. Ed. 2003, 42, 2122-2138. http://dx.doi.org/10.1002/anie.200200540

2. E. Meggers, G. E. Atilla-Gokcumen, H. Bregman, J. Maksimoska, S. P. Mulcahy, N. Pagano, D. S. Williams, Synlett 2007, 8, 1177-1189.

http://dx.doi.org/10.1055/s-2007-973893

3. E. Meggers, Curr. Opin. Chem. Biol. 2007, 11, 287-292. http://dx.doi.org/10.1016/j.cbpa.2007.05.013

4. J. E. Debreczeni, A. N. Bullock, G. E. Atilla, D. S. Williams, H. Bregman, S. Knapp, E. Meggers, Angew, Chem. Int. Ed.
2006, $45,1580-1585$.

http://dx.doi.org/10.1002/anie.200503468

5. H. Bregman, D.S. Williams, G. E. Atilla, P. J. Carroll, E. Meggers, J. Am. Chem. Soc. 2004, 126, 13594-13595.

http://dx.doi.org/10.1021/ja046049c

6. S. P. Mulcahy, P. J. Carroll, E. Meggers, Tetrahedron Lett. 2006, 47, 8877-8880.

http://dx.doi.org/10.1016/j.tetlet.2006.10.054

7. N. Stojanović, D. Urankar, A. Brozović, A. Ambriović-Ristov, M. Osmak, J. Košmrlj. Acta Chim. Slov. 2013, 60, 368- 374.

8. M. Saeidifar, H. Mansouri-Torshizi, Y. Palizdar, M. EslamiMoghaddam, A. Divsalar, A. A. Saboury, Acta Chim. Slov. 2014, 61, 126-136.

9. J. Sheikh, K. Hatzade, A. Bader, U. Shaheen, T. Sander, T. Ben Hadda, Med. Chem. Res. 2014, 23, 243-251. http://dx.doi.org/10.1007/s00044-013-0621-5

10. T. Ben Hadda, S. Srivastava, B. Das, H. Salgado-Zamora, U. Shaheen, A. Bader, M. M. Naseer, Med. Chem. Res. 2014, 23, 995-103. http://dx.doi.org/10.1007/s00044-013-0707-0

11. T. Ben Hadda, M. A. Ali, V. Masand, S. Gharby, T. Fergoug, I. Warad, Med. Chem. Res. 2013, 22, 1438-1449. http://dx.doi.org/10.1007/s00044-012-0143-6

12. T. Ben Hadda, T. Fergoug, I. Warad, Res. Chem. Intermed. 2013, 39, 1963-1971. http://dx.doi.org/10.1007/s11164-012-0729-0

13. J. Fathi, V. Masand, R. Jawarkar, R. Mouhoub, T. Ben Hadda, J. Comput. Method. Mol. Design 2011, 1, 57-68.

14. A. Jarrahpour, J. Fathi, M. Mimouni, T. Ben Hadda, J. Sheikh, Z. H. Chohan, A. Parvez, Med. Chem. Res. 2012, 21, 1984-1990. http://dx.doi.org/10.1007/s00044-011-9723-0

15. A. Parvez, M. Jyotsna, M. H. Youssoufi, T. Ben Hadda, Phosphorus, Sulfur, Silicon Relat. Elem. 2010, 185, 1500- 1510. http://dx.doi.org/10.1080/10426500903095556

16. Z. H. Chohan, S. H. Sumrra, M. H. Youssoufi, T. Ben Hadda, Eur. J. Med. Chem. 2010, 45, 2739-2747. http://dx.doi.org/10.1016/j.ejmech.2010.02.053

17. Z. H. Chohan, M. H. Youssoufi, A. Jarrahpour, T. Ben Hadda, Eur. J. Med. Chem. 2010, 45, 1189-1199. http://dx.doi.org/10.1016/j.ejmech.2009.11.029

18. A. Jarrahpour, M. Motamedifar, M. Zarei1, M. H. Youssoufi, M. Mimouni, Z. H. Chohan, T. Ben Hadda, Phosphorus, Sulfur, Silicon Relat. Elem. 2010, 185 491-497. http://dx.doi.org/10.1080/10426500902953953

19. A. Parvez, M. Jyotsna, M. H. Youssoufi, T. Ben Hadda, Phosphorus, Sulfur, Silicon Relat. Elem. 2010, 185, 15001510. http://dx.doi.org/10.1080/10426500903095556

20. B. Bennani, A. Kerbal, M. Daoudi, B. Filali Baba, G. Al Houari, A. F. Jalbout, M. Mimouni, M. Benazza, G. Demailly, M. Akkurt, S. Ö. Yildirim, T. Ben Hadda, Arkivoc 2007, 16, 19-40. http://dx.doi.org/10.3998/ark.5550190.0008.g03

21. J. Sheikh, A. Parvez, V. Ingle, H. Juneja, R. Dongre, Z. H. Chohan, M. H. Youssoufi, T. Ben Hadda, Eur. J. Med. Chem. 2011, 46, 1390-1399. http://dx.doi.org/10.1016/j.ejmech.2011.01.068

22. Z. H. Chohan, S. H. Sumrra, M. H. Youssoufi, T. Ben Hadda, J. Coord. Chem. 2010, 63, 3981-3998. 
http://dx.doi.org/10.1080/00958972.2010.523783

23. Y. N. Mabkhot, A. M. Al-Majid, A. Barakat, S. S. Al-Showiman, M. S. Al-Har, S. Radi, M. M. Naseer, T. Ben Hadda, Int. J. Mol. Sci. 2014, 15, 5115-5127.

http://dx.doi.org/10.3390/ijms15035115

24. J. Sheikh, A. Parvez, V. Ingle, H. Juneja, R. Dongre, Z. H. Chohan, M. H. Youssoufi, T. Ben Hadda, Eur. J. Med. Chem. 2011, 46, 1390-1399. http://dx.doi.org/10.1016/j.ejmech.2011.01.068

25. Z. H. Chohan, S. H. Sumrra, M. H. Youssoufi, T. Ben Hadda, J. Coord. Chem. 2010, 63, 3981-3998. http://dx.doi.org/10.1080/00958972.2010.523783

26. A. D. Becke, J. Chem. Phys. 1993, 98, 5648-5652. http://dx.doi.org/10.1063/1.464913

27. C. Lee, W. Yang, R. G. Parr, Phys. Rev. B, 1988, 37, 785- 789. http://dx.doi.org/10.1103/PhysRevB.37.785
28. C. A. Lipinski, F. Lombardo, B. W. Dominy, P. J. Feeney, Adv. Drug Deliv. Rev. 2001, 46, 3-26. http://dx.doi.org/10.1016/S0169-409X(00)00129-0

29. C. A. Lipinski, Drug Discovery Today: Technologies 2004, 1, 337-341. http://dx.doi.org/10.1016/j.ddtec.2004.11.007

30. Z. Karagoz, S. Tekin, S. Sandal, M. Genc, Res. Chem. Intermed. 2015, DOI: 10.1007/s1164-014-1545-5.

31. J. Fleming, Frontier Orbitals and Organic Chemical Reactions, Wiley, London, 1976, 111-155.

32. D. Sajan, K. U. Lakshmi, Y. Erdogdu, I. H. Joe, Spectrochim. Acta 2011, 78A, 113-121. http://dx.doi.org/10.1016/j.saa.2010.09.007

33. B. Eren, A. Unal, Spectrochim. Acta Part A 2013, 103, 222231. http://dx.doi.org/10.1016/j.saa.2012.10.055

\section{Povzetek}

Razvili smo računski model Petra/Osiris/Molinspiration/DFT(POM/DFT) za določitev fizikalno-kemijskih parametrov, ki določajo biološko aktivnost rutenij-stavrosporin kompleksov 2-4 s farmakofornim mestom antitumor-kinaze (TK). Analiziranim štirim spojinam 1-4 so bile že predhodno testirane njihove antitumorne aktivnosti; spojini $\mathbf{2}$ in $\mathbf{4}$ sta nevtralni, medtem ko je analog 3 monokation z rutenijevim(II) centrom. Največja antitumorna aktivnost je bila dosežena pri spojinah 3 in 4, ki imata nizko $\mathrm{IC}_{50}$ vrednost $(0.45$ in $8 \mathrm{nM}$ ), kar prekaša derivat stavrosporina (piridokarbazol 1, 150 • $\left.10^{3} \mathrm{nM}\right) . \mathrm{IC}_{50}$ vrednost za $3(0.45 \mathrm{nM})$ predstavlja 20.000-kratno povečanje aktivnosti glede na derivat stavrosporina $\mathbf{1}$. Povečanje bioaktivnosti je možno pripisati nastanku pi-prenosa naboja s kompleksa kovina-stavrosporin na $\mathrm{CO}^{\delta-}-\mathrm{NH}^{\delta+}$ antitumorno farmakoforno mesto. 